\title{
Association of a chromosome 1q21 locus in close proximity to a late cornified envelope-like proline-rich 1 ( $L E L P 1)$ gene with total serum IgE levels
}

\author{
Mamta Sharma $\cdot$ Kamiya Mehla $\cdot$ Jyotsna Batra • \\ Balaram Ghosh
}

Received: 5 October 2006/ Accepted: 13 January 2007/Published online: 15 February 2007

(C) The Japan Society of Human Genetics and Springer 2007

\begin{abstract}
The chromosomal region 1q21 has been linked to atopic dermatitis in previous studies. Seven polymorphic repeats were identified in a $0.5 \mathrm{Mb}$ region of chromosome 1q21 encompassing a small prolinerich protein $(S P R R)$ gene cluster, a few $S 100$ gene family members, loricin, and several uncharacterized genes. These repeats were genotyped by fragment length polymorphism analysis in 133 atopic case-parent trios, of which 111 probands had atopic asthma. Our trio-based analysis for association with atopy and atopic asthma revealed no significant allelic or genotypic association for any of the seven loci tested. However, a significant association was observed with locus 5 (3.65 Mb of contig NT_032962) and $\log _{10}$ serum IgE levels $(F=3.93, P=0.0008)$. Results were also replicated in an independent case-control cohort $\left(N_{\mathrm{p}}=165, N_{\mathrm{c}}=166\right)$, where a significant association with $\log _{10}$ serum $\operatorname{IgE}$ levels was observed in the patient group $(P=0.0005)$. Interestingly, locus 5 is $6.2 \mathrm{~kb}$ upstream of a late cornified envelope-like proline-rich 1 (LELP1) gene which encodes a novel small proline rich protein. Further, we have also found a significant association of rs7534334 (tagged SNP from LELP1) SNP with $\log _{10}$ serum IgE levels in the patient group $(P=0.0029)$. Thus, our results identify a chromosomal
\end{abstract}

Electronic supplementary material The online version of this article (doi:10.1007/s10038-007-0118-5) contains supplementary material which is available to authorized users.

M. Sharma · K. Mehla · J. Batra · B. Ghosh $(\bowtie)$

Molecular Immunogenetics Laboratory,

Institute of Genomics and Integrative Biology,

Mall Road, Delhi 110007, India

e-mail: bghosh@igib.res.in region in close proximity to a novel gene and highlight the need for intense research on LELP1 and other genes close by with respect to atopic disorders.

Keywords Asthma - Atopy · 1q21 - IgE - QTDT . LELP1

\section{Introduction}

Atopic asthma is a complex polygenic disorder characterized by allergen-induced inflammation of the airways and high Th2-mediated IgE humoral response (Ghosh et al. 2003). The chromosome 1q21 region has been shown to be linked to atopic dermatitis and psoriasis, an inflammatory skin condition, with a peak linkage overlying the epidermal differentiation complex (EDC) spanning a region of $2.05 \mathrm{Mb}$ (Cookson et al. 2001; Capon et al. 1999; Bhalerao et al. 1998). The EDC contains various important genes, such as involucrin $(I V L)$, loricin $(L O R)$, the small proline-rich protein $(S P R R)$ gene family, profilaggrin $(F L G)$ and trichohyalin $(\mathrm{THH})$ encoding structural components of the epidermis, and the S100 gene family encoding calcium-binding proteins involved in signal transduction and cell cycle progression (Marenholz et al. 1996). Interestingly, in recent studies, two null mutations in the $F L G$ gene were found to be associated with atopic dermatitis and asthma occurring in the context of atopic dermatitis (Palmer et al. 2006, Marenholz et al. 2006).

Towards the telomeric end of the EDC, within a span of $0.5 \mathrm{Mb}$, several genes such as a $S P R R$ gene cluster, loricin, $S 100 A 8, A 9, A 12, A 15$, and several uncharacterized genes are present (Fig. 1). The serum 


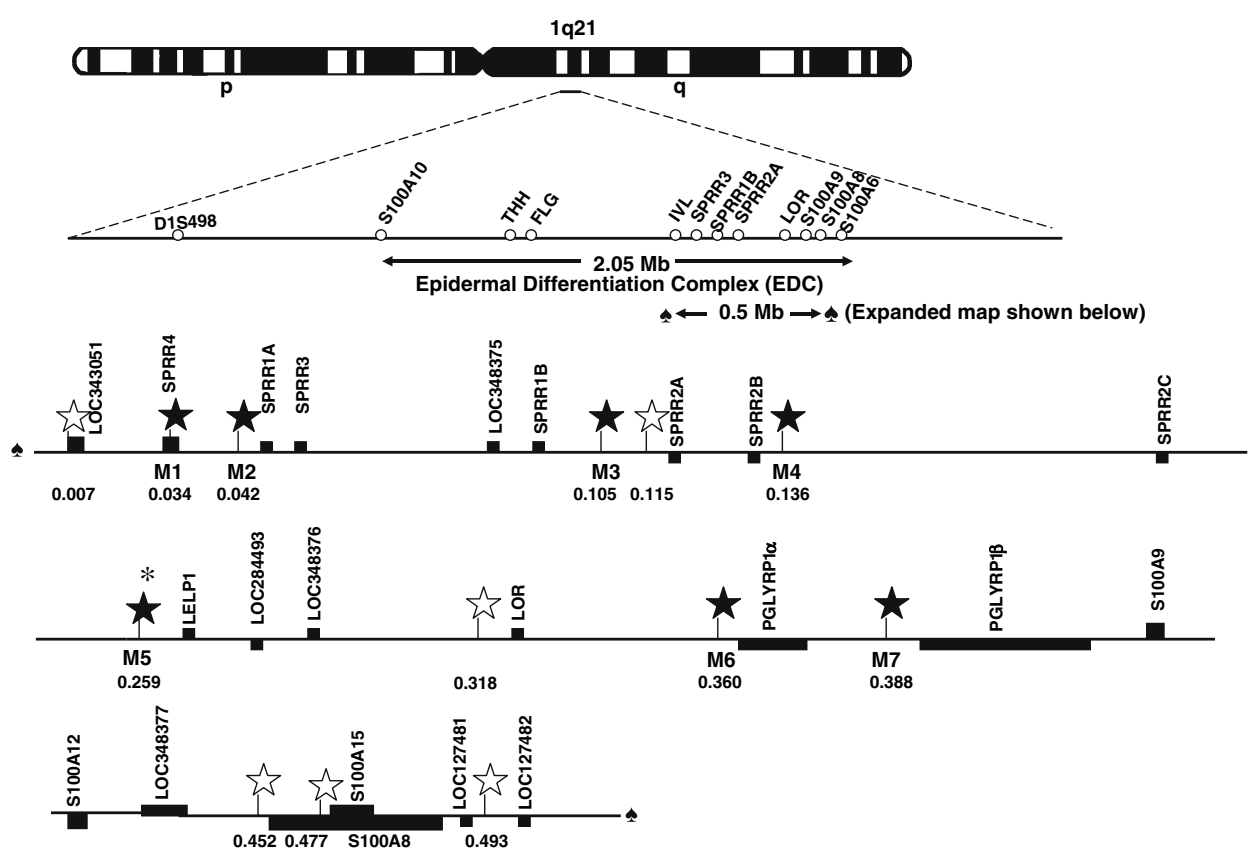

Fig. 1 Earlier linkage studies with atopic disorders identified a peak of linkage at the D1S498 marker overlying the EDC spanning a region of $\sim 2 \mathrm{Mb}$ on chromosome 1q21. This region has an S100 gene cluster and the epidermal differentiation genes. Simple repeats were identified in this $0.5 \mathrm{Mb}$ region $(3.4-3.9 \mathrm{Mb}$ of contig NT_032962), spanning the important inflammatory

levels of the S100A8 and A9 protein complex (calprotectin) are found to be raised above normal levels under many inflammatory conditions (Sorg et al. 1992). Moreover, the S100A8 homodimer is a potent chemotactic factor for leukocytes (Passey et al. 1999) and S100A12 exhibits proinflammatory activity on endothelial cells and inflammatory cells (Hofmann et al. 1999). Microarray studies on skin biopsy samples of patients suffering from atopic dermatitis revealed an increased expression of S100A7, S100A8 and downregulation of filaggrin and loricrin (Sugiura et al. 2005). Recent studies using allergen-induced asthma models revealed overexpression of the $S P R R 2 A$ and $S P R R 2 B$ genes in subsets of bronchial epithelial cells and mononuclear cells (Zimmermann et al. 2005).

Thus, a number of inflammatory candidate genes and several uncharacterized genes are present within a distance of $0.5 \mathrm{Mb}$ on chromosome 1q21. However, an association study to identify the genes associated with atopic disorders from this region has not yet been performed. In this study we have investigated the genetic association of simple repeat markers in this region with atopy, atopic asthma and serum IgE level phenotypes in the Indian population. The association was further validated using tagged single nucleotide polymorphisms (SNPs) within the LELP1 gene. candidate genes on chromosome 1q21. The position of each repeat is given in $\mathrm{Mb}$ within the $0.5 \mathrm{Mb}$ region. Polymorphic and nonpolymorphic repeats are marked with solid and open stars, respectively. Significant association with serum $\operatorname{IgE}$ levels was observed at the $0.259 \mathrm{Mb}$ position, as shown by an asterisk

\section{Materials and methods}

The study population consisted of 133 atopic caseparent trios, of which 111 probands had atopic asthma. Patients and the family members were recruited from hospitals in North India. An independent case (atopic asthma)-control (normal nonasthmatic individuals) cohort $\left(N_{\mathrm{p}}=165, N_{\mathrm{c}}=166\right)$ was also collected. Ethical approval was obtained from the Institutional Review Board. Written informed consent was obtained from all participating individuals. Patients were diagnosed by physicians for asthma according to the guidelines of the National Asthma Education and Prevention Program (Expert Panel Report 2, 2002) and were examined for a self-reported history of breathlessness, wheezing and for family history (Nagpal et al. 2005). Atopic individuals gave a positive skin prick test (SPT) for at least one of the fifteen common environmental allergens and suffered from asthma, allergic rhinitis or atopic dermatitis. The demographic and clinical details of the study population are given in Table 1 . Genetic homogeneity between the patients and the control group was confirmed by genotyping various loci that have yet to be linked to asthma-related disorders (Batra et al. 2005). Total serum IgE levels were estimated using enzyme-linked immunosorbent assay 
Table 1 Demographic profile of the study population

\begin{tabular}{llll}
\hline & Trio-based study & Case-control study \\
\cline { 3 - 4 } & $\begin{array}{l}\text { Atopic asthmatic } \\
\text { probands }\end{array}$ & $\begin{array}{l}\text { Atopic } \\
\text { asthmatics }\end{array}$ \\
\hline Number of individuals: & 111 & 165 & 166 \\
Age & $16.59( \pm 10.9)$ & $25.87( \pm 16.7)$ \\
Mean $\log _{10}$ IgE & $3.01( \pm 0.69)$ & $3.07( \pm 0.74)$ & $23.74( \pm 8.6)$ \\
Sex ratio (M:F) & $0.60: 0.40$ & $0.59: 0.41$ & $2.21( \pm 0.76)$ \\
Asthma & All & All & All \\
SPT positivity/atopy* & All & None & None \\
Smoking history & None & All & None \\
Frequent episodes of wheezing & All & $<70 \%$ & None \\
FEV1/FVC at the time of attack & $<70 \%$ & $>12 \%$ & NA \\
Percent reversibility using bronchodilator & $>12 \%$ & All & ND \\
Asthma therapy & All & NA \\
\hline
\end{tabular}

Patients and their family members were recruited from states in North India, viz: Delhi, Haryana and Punjab. Controls were also collected from the same area

Parentheses contain standard deviation values. $N A$ indicates not applicable and $N D$ indicates not done

*Patients tested positive for at least one of the 15 most common environmental allergens

(ELISA) (Bethyl Labs, Montgomery, TX, USA). The NCBI nucleotide sequence NT_032962 was taken and the region 3.41-3.9 Mb was scanned for simple repeats using the RepeatMasker program. A total of 13 such repeats (Fig. 1) were identified. Primers were designed using DNASTAR PrimerSelect software in order to amplify the identified repeat regions (Supplementary Table 1). The forward primers were fluorescently labeled with FAM/HEX. PCR amplification was performed from the DNA from 20 normal individuals, and samples were electrophoresed using the ABI Prism 3100 Genetic Analyzer (Applied Biosystems, Foster City, CA, USA) as per the manufacturer's instructions. Fragment lengths were determined using the GeneScan/Genotyper v3.7 (Applied Biosystems). The seven polymorphic loci (Fig. 1, marked with solid stars) were genotyped in all of the individuals. Two tagged SNPs (rs11576296 in intron 1 and rs7534334, 255 bp downstream of the LELP1) in/around the LELP1 gene were identified using the HAPMAP database and were also genotyped using the SNaPshot ddNTP Primer Extension Kit (Applied Biosystems) using the primers detailed in Supplementary Table 1. These samples were subsequently electrophoresed using the ABI Prism 3100 Genetic Analyzer (Applied Biosystems) as per the manufacturer's instructions.

Mendelian inconsistencies during the transmission of alleles at the seven loci were checked using the Pedcheck program. An extended transmission disequilibrium test (E-TDT) for multi-allelic marker (http://www.mds. qmw.ac.uk/statgen/dcurtis/software.html) was carried out for the seven multi-allelic markers. In TDT, a parent heterozygous for an associated allele A1 and nonasso- ciated allele A2 should transmit A1 more often to an affected child than A2. A quantitative transmission/ disequilibrium test (QTDT) (Abecasis et al. 2000) was carried out for the serum $\log _{10} \operatorname{IgE}$ levels in families. The QTDT test statistics were obtained using likelihood-ratio tests, assuming normal distributions for the traits. An empirical $P$ value that is based on the permutation of genotypes is obtained to protect against possible deviations from either normality or selection on the trait (http://www.sph.umich.edu/csg/abecasis/QTDT/download/index.html). A global $P$ value was calculated for multi-allelic marker alleles using the multi-allelic option with the orthogonal test. When this option is used, rare alleles (i.e., those with a frequency of $\leq 5 \%$ in the total genotyped sample) are clumped together and individual effects for all other alleles are estimated, producing a single $P$ value per marker/phenotype pair. Allelic and genotypic associations with atopic asthma were analyzed in the case-control study using JMP Version 4.0.2 (SAS Institute Inc., Cary, NC, USA) or the Armitage trend test. Allelic or genotypic association with serum $\log _{10}$ IgE levels was assessed for the case and control groups using one-way ANOVA.

\section{Results and discussion}

In our study, we identified thirteen simple repeats in the $0.5 \mathrm{Mb}$ region of chromosome 1q21 in close proximity to several important candidate genes in this region: SPRR genes, S100A8, S100A9, and several other uncharacterized genes (Fig. 1). Seven loci-at positions 3.43 (M1), 3.44 (M2), 3.5 (M3), 3.53 (M4), 3.65 
(M5), 3.76 (M6) and 3.78 Mb (M7)—were found to be polymorphic whereas six loci-at positions $3.4,3.5,3.7$, 3.85, 3.87 and $3.89 \mathrm{Mb}$-of contig NT_032962 were found to be nonpolymorphic in the Indian population (Fig. 1). The heterozygosity index of each polymorphic locus was greater than 0.75 . Since the markers were in close proximity to several candidate genes in this region, they could be used in an association study, which involves directly analyzing the polymorphism within the gene of interest or the markers in strong linkage disequilibrium with this gene (Risch and Merikangas 1996). E-TDT analysis of 133 atopic trios and 111 atopic asthmatic trios revealed no significant association with either atopy or atopic asthma for any of the simple repeat markers tested. The association of the seven loci with $\log _{10}$ serum $\operatorname{IgE}$ levels was tested in 119 out of the 133 atopic trios, because serum IgE levels could not be estimated for 14 probands. Out of these 119 atopic probands, 98 had asthma. A significant association $(F=3.926, P=0.0008)$ was observed with serum $\log _{10} \operatorname{IgE}$ levels in the 119 families at locus 5 (Table 2) using the orthogonal association model. In addition, when dominance was taken to be a covariate in the orthogonal model, a significant association was observed at locus $5(F=2.66, P=0.0035)$ and locus 6 $(F=1.86, P=0.0417)$. The association at locus 5 was significant in both models after Bonforreni correction for seven tests (the number of markers tested) $[P=0.0056$ (orthogonal model), $P=0.0245$ (orthogonal dominance)].

Further, no allelic or genotypic association of the seven loci with atopic asthma was observed in an independent case-control study. However, ANOVA analysis for association with $\log _{10} \operatorname{IgE}$ levels showed a significant association of locus 5 alleles in the patient group (Table 3). Using a Tukey-Kramer HSD test, we found a significant difference between the mean of $\log _{10}$ $\mathrm{IgE}$ for allele 6 and the mean of $\log _{10} \operatorname{IgE}$ for allele 10 $(P<0.01)$. It should be noted that a similar association was not obtained in the control group, so this locus could be associated with $\mathrm{IgE}$ levels specifically in asthmatic individuals, or it could be associated with severity of asthma but not with $\operatorname{IgE}$ in general. Locus 5 is present $6.2 \mathrm{~kb}$ upstream of the LELP1 gene that encodes a novel small proline-rich protein (SPRR). This gene is uncharacterized as yet, and its exact function is unknown. Still, in order to strengthen our results further, we selected tagged SNPs from the HAPMAP database present in and around the LELP1 gene and analyzed their associations. None of the two SNPs (i.e., rs11576296 and rs7534334) showed a significant association with asthma in our case-control studies $(P>0.5)$. Nevertheless, rs7534334 (255 bp downstream of the $L E L P 1)$ was found to be significantly associated with $\log _{10}$ IgE levels in the patient cohort (Table 3).

Recently, Palmer et al. (2006) identified an association of two null mutations in the FLG gene, present nearly $0.8 \mathrm{Mb}$ upstream of $L E L P 1$, with atopic dermatitis as well as asthma. The filaggrin protein is directly implicated in atopic dermatitis because of its involvement in skin barrier formation. These mutations were found to be a strong predisposing factor for atopic dermatitis as well as asthma occurring in the context of atopic dermatitis (nearly $50 \%$ of the asthmatics had atopic dermatitis). However, no association was observed with asthma in the absence of atopic dermatitis $(\mathrm{OR}=0.8)$. Atopic dermatitis constituted less than 5\% of our total study population, so the association that we

Table 2 E-TDT and QTDT analyses at seven loci with atopic asthma $(N=111)$, atopy $(N=133)$ and total serum $\operatorname{IgE}(N=119)$ phenotypes

\begin{tabular}{|c|c|c|c|c|c|c|c|c|}
\hline \multirow[t]{3}{*}{ Locus } & \multicolumn{4}{|l|}{ E-TDT } & \multicolumn{4}{|c|}{ QTDT } \\
\hline & \multirow[t]{2}{*}{ Repeat } & \multirow[t]{2}{*}{ Alleles } & \multirow{2}{*}{$\begin{array}{l}\text { Atopic asthma } \\
(P=\text { Allelic, } \\
\text { Genotypic })\end{array}$} & \multirow{2}{*}{$\begin{array}{l}\text { Atopy } \\
(P=\text { Allelic, } \\
\text { Genotypic })\end{array}$} & \multicolumn{2}{|c|}{ Orthogonal } & \multicolumn{2}{|c|}{ Orthogonal dominance } \\
\hline & & & & & $F$ & $P$ value & $F$ & $P$ value \\
\hline $3.43 \mathrm{Mb}(\mathrm{M} 1)$ & $(\mathrm{CA}) \mathrm{n}$ & 7 & $P=0.8,0.7$ & $P=0.7,0.6$ & 0.99 & 0.3990 & 1.87 & 0.0818 \\
\hline $3.44 \mathrm{Mb}(\mathrm{M} 2)$ & $\begin{array}{l}\text { (CT)m } \\
\quad(\mathrm{CA}) \mathrm{n}\end{array}$ & 8 & $P=0.47,0.16$ & $P=0.77,0.26$ & 1.52 & 0.2238 & 0.43 & 0.8243 \\
\hline $3.5 \mathrm{Mb}(\mathrm{M} 3)$ & $(\mathrm{CA}) \mathrm{n}$ & 8 & $P=0.59,0.09$ & $P=0.63,0.08$ & 1.39 & 0.2351 & 1.57 & 0.1448 \\
\hline $3.53 \mathrm{Mb}(\mathrm{M} 4)$ & $(\mathrm{CA}) \mathrm{n}$ & 11 & $P=0.56,0.08$ & $P=0.49,0.09$ & 0.34 & 0.7954 & 1.06 & 0.3930 \\
\hline $3.65 \mathrm{Mb}(\mathrm{M} 5)$ & $(\mathrm{GT}) \mathrm{n}$ & 15 & $P=0.16,0.17$ & $P=0.37,0.18$ & 3.93 & $0.0008^{*}$ & 2.66 & $0.0035^{*}$ \\
\hline $3.76 \mathrm{Mb}(\mathrm{M} 6)$ & $\begin{array}{l}\text { (GA)m } \\
\quad(\text { GGAA)n }\end{array}$ & 15 & $P=0.74,0.37$ & $P=0.67,0.18$ & 1.14 & 0.3450 & 1.86 & $0.0417 *$ \\
\hline $3.78 \mathrm{Mb}(\mathrm{M} 7)$ & $(\mathrm{GT}) \mathrm{n}$ & 8 & $P=0.13,0.19$ & $P=0.28,0.39$ & 0.59 & 0.6239 & 1.96 & 0.0778 \\
\hline
\end{tabular}

QTDT analysis was performed using an orthogonal model. Dominance was used as a covariate in the orthogonal dominance model *Significant $P$ value 
Table 3 Allelic/genotypic associations with $\log _{10}$ serum IgE levels assessed using one-way ANOVA

\begin{tabular}{|c|c|c|c|c|c|c|c|c|c|c|}
\hline \multirow{2}{*}{$\begin{array}{l}\text { Locus } 5 \\
\text { (allele no.) * }\end{array}$} & \multicolumn{5}{|c|}{ Atopic asthmatics $(N=165)$} & \multicolumn{5}{|c|}{ Controls $(N=166)$} \\
\hline & $\begin{array}{l}\text { Number of } \\
\text { individuals }\end{array}$ & $\begin{array}{l}\text { Mean } \log _{10} \\
\text { serum } \operatorname{IgE} \pm \mathrm{SD}\end{array}$ & DF & $F$ Ratio & $P$ value & $\begin{array}{l}\text { Number of } \\
\text { individuals }\end{array}$ & $\begin{array}{l}\text { Mean } \log _{10} \\
\text { serum } \operatorname{IgE} \pm \mathrm{SD}\end{array}$ & DF & $F$ Ratio & $P$ value \\
\hline 1 & 27 & $2.94 \pm 0.54$ & \multirow[t]{10}{*}{9} & \multirow[t]{10}{*}{3.4} & \multirow[t]{10}{*}{0.0005} & 16 & $2.46 \pm 0.64$ & \multirow[t]{10}{*}{11} & \multirow[t]{10}{*}{1.27} & \multirow[t]{10}{*}{0.24} \\
\hline 3 & 52 & $3.03 \pm 0.43$ & & & & 64 & $2.17 \pm 0.77$ & & & \\
\hline 6 & 85 & $2.92 \pm 0.48$ & & & & 82 & $2.32 \pm 0.76$ & & & \\
\hline 7 & 8 & $3.49 \pm 0.12$ & & & & 5 & $2.01 \pm 0.49$ & & & \\
\hline 8 & 24 & $2.82 \pm 0.62$ & & & & 18 & $2.42 \pm 0.82$ & & & \\
\hline 9 & 6 & $2.80 \pm 0.79$ & & & & 6 & $2.15 \pm 0.75$ & & & \\
\hline 10 & 57 & $3.32 \pm 0.88$ & & & & 77 & $2.24 \pm 0.63$ & & & \\
\hline 11 & 20 & $2.81 \pm 0.54$ & & & & 22 & $1.85 \pm 0.65$ & & & \\
\hline 12 & 16 & $2.93 \pm 0.48$ & & & & 10 & $2.21 \pm 0.59$ & & & \\
\hline 13 & 9 & $2.70 \pm 0.46$ & & & & 7 & $1.90 \pm 0.86$ & & & \\
\hline \multicolumn{11}{|c|}{ LELP1-rs11576296 (G/A) } \\
\hline GG & 38 & $3.02 \pm 0.67$ & \multirow[t]{3}{*}{2} & \multirow[t]{3}{*}{0.62} & \multirow[t]{3}{*}{0.53} & 20 & $2.53 \pm 0.89$ & \multirow[t]{3}{*}{2} & \multirow[t]{3}{*}{1.74} & \multirow[t]{3}{*}{0.17} \\
\hline GA & 72 & $3.04 \pm 0.78$ & & & & 103 & $2.18 \pm 0.74$ & & & \\
\hline AA & 47 & $3.18 \pm 0.74$ & & & & 36 & $2.21 \pm 0.72$ & & & \\
\hline \multicolumn{11}{|c|}{ LELP1-rs7534334 (C/T) } \\
\hline $\mathrm{CC}$ & 78 & $2.92 \pm 0.59$ & \multirow[t]{3}{*}{2} & \multirow[t]{3}{*}{6.08} & \multirow[t]{3}{*}{0.0029} & 87 & $2.23 \pm 0.83$ & \multirow[t]{3}{*}{2} & \multirow[t]{3}{*}{8.2} & \multirow[t]{3}{*}{0.44} \\
\hline $\mathrm{CT}$ & 53 & $3.12 \pm 0.72$ & & & & 64 & $2.15 \pm 0.73$ & & & \\
\hline TT & 22 & $3.49 \pm 0.91$ & & & & 14 & $2.43 \pm 0.52$ & & & \\
\hline
\end{tabular}

*Alleles with counts of less than 5 were excluded from the analysis

obtained is unlikely to be due to the involvement of the $F L G$ gene mutations. On the other hand, our findings of the association of a repeat and a SNP in the proximity of the LELP1 gene with IgE levels could also be related to atopic dermatitis, as IgE levels are elevated in atopic asthma as well as atopic dermatitis (Jones et al. 1975). It would, therefore, be interesting to study this locus, specifically $L E L P 1$ with atopic dermatitis, in the future. In any event, it is very likely that the EDC region on the 1q21 chromosome contains multiple loci such as FLG and $L E L P 1$, which are involved in atopic disorders.

Interestingly, the SPRR $2 A$ and $S P R R 2 B$ genes from the same SPRR family to which the LELP1 belongs were observed to be induced in the lungs of allergen-challenged mice via in situ hybridization (Zimmermann et al. 2005). This induction was found to be dependent on IL-13 and STAT-6. Studies in STAT-6 knock-out mice suggest that it is an essential transcription factor for class switching to IgE (Shimoda et al. 1996). Thus, the expression of the novel small proline-rich protein LELP1 might be regulated by the same STAT-6 protein that regulates the expression of $\operatorname{IgE}$. This could explain the association of LELP1 with serum IgE levels. However, this could also be due to linkage disequilibrium of the locus 5 marker and/or rs7534334 SNP with genetic variations in some other genes in this vicinity. Nevertheless, our study narrows down the chromosome 1q21 region associated with serum $\operatorname{IgE}$ levels, and it should prove helpful for identifying gene(s) associated with atopic disorders.

Acknowledgments We thank our collaborating physicians for helping us during sample collection. We also thank all patients and their family members for participating in this study. The financial support from the Task Force Project SMM 0006 of the Council of Scientific and Industrial Research (CSIR), Govt. of India is greatly acknowledged. MS, KM and JB acknowledge CSIR for their fellowships. The help provided by Rana Nagarkatti, Abha Soni, Tej Pratap Singh and Deepti Mann is sincerely acknowledged.

\section{References}

Abecasis GR, Cardon LR, Cookson WO (2000) A general test of association for quantitative traits in nuclear families. Am J Hum Genet 66(1):279-292

Batra J, Niphadkar PV, Sharma SK, Ghosh B (2005) Uteroglobin-related protein 1(UGRP1) gene polymorphisms and atopic asthma in the Indian population. Int Arch Allergy Immunol 136(1):1-6

Bhalerao J, Bowcock AM (1998) The genetics of psoriasis-a complex disorder of the skin and immune system. Hum Mol Genet 7:1537-1545

Capon F, Novelli G, Semprini S, Clementi M, Nudo M, Vultaggio P, Mazzanti C, Gobello T, Botta A, Fabrizi G, Dallapiccola B (1999) Searching for psoriasis susceptibility genes in Italy: genome scan and evidence for a new locus on chromosome 1. J Invest Dermatol 112:32-35 
Cookson WO, Ubhi B, Lawrence R, Abecasis GR, Walley AJ, Cox HE, Coleman R, Leaves NI, Trembath RC, Moffatt MF, Harper JI (2001) Genetic linkage of childhood atopic dermatitis to psoriasis susceptibility loci. Nat Genet 27(4):372-373

Ghosh B, Sharma S, Nagarkatti R (2003) Genetics of asthma: current research paving the way for development of personalized drugs. Indian J Med Res 117:185-197

Hofmann MA, Drury S, Fu C, Qu W, Taguchi A, Lu Y, Avila C, Kambham N, Bierhaus A, Nawroth P, Neurath MF, Slattery T, Beach D, McClary J, Nagashima M, Morser J, Stern D, Schmidt AM (1999) RAGE mediates a novel proinflammatory axis: a central cell surface receptor for S100/calgranulin polypeptides. Cell 97:889-901

Jones HE, Inouye JC, McGerity JL, Lewis CW (1975) Atopic disease and serum immunoglobulin-E. $\mathrm{Br} \mathrm{J}$ Dermatol 92(1):17-25

Marenholz I, Volz A, Ziegler A, Davies A, Ragoussis I, Korge BP, Mischke D (1996) Genetic analysis of the epidermal differentiation complex (EDC) on human chromosome 1q21: chromosomal orientation, new markers, and a 6-Mb YAC contig. Genomics 37(3):295-302

Marenholz I, Nickel R, Ruschendorf F, Schulz F, EsparzaGordillo J, Kerscher T, Gruber C, Lau S, Worm M, Keil T, Kurek M, Zaluga E, Wahn U, Lee YA (2006) Filaggrin lossof-function mutations predispose to phenotypes involved in the atopic march. J Allergy Clin Immunol 118(4):866-871

Nagpal K, Sharma S, B-Rao C, Nahid S, Niphadkar PV, Sharma SK, Ghosh B (2005) TGF beta1 haplotypes and asthma in Indian populations. J Allergy Clin Immunol 115(3):527-533

Palmer CN, Irvine AD, Terron-Kwiatkowski A, Zhao Y, Liao H, Lee SP, Goudie DR, Sandilands A, Campbell LE, Smith FJ, O'regan GM, Watson RM, Cecil JE, Bale SJ, Compton JG,
Digiovanna JJ, Fleckman P, Lewis-Jones S, Arseculeratne G, Sergeant A, Munro CS, El Houate B, McElreavey K, Halkjaer LB, Bisgaard H, Mukhopadhyay S, McLean WH (2006) Common loss-of-function variants of the epidermal barrier protein filaggrin are a major predisposing factor for atopic dermatitis. Nat Genet 38(4):441-446

Passey RJ, Xu K, Hume DA, Geczy CL (1999) S100A8: emerging functions and regulation. J Leukoc Biol 66:549556

Risch N, Merikangas K (1996) The future of genetic studies of complex human diseases. Science 273:1516-1517

Shimoda K, van Deursen J, Sangster MY, Sarawar SR, Carson RT, Tripp RA, Chu C, Quelle FW, Nosaka T, Vignali DA, Doherty PC, Grosveld G, Paul WE, Ihle JN (1996) Lack of IL-4-induced Th2 response and IgE class switching in mice with disrupted Stat6 gene. Nature 380:630-633

Sorg C (1992) The calcium binding proteins MRP8 and MRP14 in acute and chronic inflammation. Behring Inst Mitt 91:126-137

Sugiura H, Ebise H, Tazawa T, Tanaka K, Sugiura Y, Uehara M, Kikuchi K, Kimura T (2005) Large-scale DNA microarray analysis of atopic skin lesions shows overexpression of an epidermal differentiation gene cluster in the alternative pathway and lack of protective gene expression in the cornified envelope. Br J Dermatol 152(1):146-149

Zimmermann N, Doepker MP, Witte DP, Stringer KF, Fulkerson PC, Pope SM, Brandt EB, Mishra A, King NE, Nikolaidis NM, Wills-Karp M, Finkelman FD, Rothenberg ME (2005) Expression and regulation of small proline-rich protein 2 in allergic inflammation. Am J Respir Cell Mol Biol 32(5):428-435 